Abstracta Iranica Iranica

Revue bibliographique pour le domaine irano-aryen

Volume 28 | 2007

Comptes rendus des publications de 2005

\title{
Iron Age Funerary Stelae from Lebanon. Barcelone, 2005, 169 p. et 118 fig.
}

\section{Astrid Nunn}

\section{(2) OpenEdition}

1 Journals

\section{Édition électronique}

URL : http://journals.openedition.org/abstractairanica/16342

DOI : 10.4000/abstractairanica. 16342

ISSN : 1961-960X

Éditeur :

CNRS (UMR 7528 Mondes iraniens et indiens), Éditions de l'IFRI

Édition imprimée

Date de publication : 15 mai 2007

ISSN : 0240-8910

\section{Référence électronique}

Astrid Nunn, «Iron Age Funerary Stelae from Lebanon. Barcelone, 2005, 169 p. et 118 fig. », Abstracta Iranica [En ligne], Volume 28 | 2007, document 115, mis en ligne le 18 septembre 2007, consulté le 25 septembre 2020. URL : http://journals.openedition.org/abstractairanica/16342 ; DOI : https://doi.org/ 10.4000/abstractairanica.16342

Ce document a été généré automatiquement le 25 septembre 2020.

Tous droits réservés 


\title{
Iron Age Funerary Stelae from Lebanon. Barcelone, 2005, 169 p. et 118 fig.
}

\author{
Astrid Nunn
}


Quand on pense stèles phéniciennes (au sens large), ce sont les très nombreuses stèles puniques de Carthage, puis celles de Sardaigne et de Sicile qui viennent à l'esprit. Ce volume présente 62 stèles trouvées au Liban. Seules 13 proviennent des fouilles régulières de Tell Burak (1), Khalde (1), Sidon (1) et Tyre (10). Les autres ont été pillées ou trouvées accidentellement, certaines il y a longtemps, et accessoirement publiées. La grande majorité remonte à l'âge du Fer, sept sont achéménides. Le but de ce livre était de rassembler ce matériel disséminé. Un premier chapitre le présente (pp. 15-88). Les stèles sont décrites et datées d'après des critères paléographiques et archéologiques, quand cela est possible. Le chapitre II est consacré à l'épigraphie et à l'onomastique (pp. 89-114). Les symboles gravés sur les stèles, disques solaires, croissants lunaires, bétyles, signes hiéroglyphiques et pseudo-hiéroglyphiques, croix, triangles et niches font l'objet du Chapitre III (pp. 115-138). Les sept «stèles» de la période ( ${ }^{\circ}{ }^{53-59)}$ achéménides - en réalité cinq sont communément désignées de naiskoi - se distinguent clairement de la période précédente. Toutes portent une niche surplombée d'un disque solaire en général ailé et d'une frise d'urei. Trouvées sans contexte, leur fonction a été débattue pendant longtemps et il semble maintenant hors de doute que ces petits monuments - ils mesurent entre 60 et $90 \mathrm{~cm}$ de hauteur - se trouvaient à l'origine dans un contexte funéraire. Malgré le hasard qui entoure le groupement de ces stèles, l'A. pense que leur usage dans les nécropoles n'était pas systématique. Les uniques cimetières correctement fouillés de Khalde et Sidon-Dakerman n'ont révélé qu'une stèle chacun. Sept stèles seulement sont répertoriées pour les environs de Sidon, où des centaines de tombes sont connues. En tout cette publication est extrêmement intéressante et servira peut-être également à ralentir le pillage archéologique au Liban (comme cela avait été l'intention de R. Stucky en publiant les «temple boys » dans Die Skulpturen aus dem Eschmun-Heiligtum bei Sidon. Griechische, römische, kyprische und phönizische Statuen und Reliefs vom 6. Jahrhundert vor Chr. bis zum 3. Jahrhundert n. Chr., Antike Kunst, Beiheft 17, Bâle, 1993).

\section{INDEX}

Thèmes : 3.2.2. Pré-Achéménides et Achéménides

\section{AUTEURS}

\section{ASTRID NUNN}

Université de Munich 